\title{
PENGARUH GAYA KEPEMIMPINAN, MOTIVASI DAN DISIPLIN KERJA TERHADAP KINERJA KARYAWAN PT. FINANCIA MULTI FINANCE PALOPO
}

\author{
Hapid 1 \\ Acep Rochmat Sunarwan ${ }^{2}$
}

No. HP $081242455731^{1}$

\section{ABSTRAK}

Penelitian ini bertujuan untuk menguji dan menganalisis pengaruh gaya kepemimpinan, motivasi dan disiplin kerja terhadap kinerja karyawan PT. Financia Multi Finance Palopo. Pengumpulan data dilakukan melalui penyebaran kuesioner dan dilaksanakan pada 80 karyawan Financia Multi Finance Palopo. Analisis data pada penelitian ini menggunakan bantuan SPSS versi 20. Teknik sampling yang dipakai adalah metode sensus dan teknik pengujian data yang digunakan dalam penelitian ini analisis regresi liner berganda, untuk menguji dan membuktikan hipotesis penelitian.

Hasil analisis menunjukkan bahwa gaya kepemimpinan, motivasi, dan disiplin kerja berpengaruh positif terhadap kinerja karyawan.

\section{Kata Kunci: Gaya kepemimpinan, Motivasi, Disiplin Kerja dan Kinerja Karyawan.}

\section{PENDAHULUAN}

PT. Finansia Multi Finance dengan brand kreditplus, didirikan pada tanggal 9 Juni 1994 dan per 31 Januari 2013 telah mempunyai 311 lokasi kantor yang tersebar di seluruh Indonesia. Memegang ijin usaha untuk menjalankan roda usaha pembiayaan, anjak piutang dan kartu kredit. Merupakan suatu badan usaha bersama dua perusahaan multi nasional (satu perusahaan gabungan profesional Indonesia dan Singapura dan satu perusahaan Amerika).
Kecepatan pelayanan dalam pengajuan aplikasi, kemudahan syarat dan pembayaran dipertahankan sampai saat ini sehingga menjadi unggulan dari kreditplus untuk bersaing dengan perusahaan pembiayaan lainnya.

$$
\text { Persaingan }
$$

mengakibatkan perusahaan-perusahaan dituntut untuk mampu bertahan dan semakin dapat memacu dirinya untuk berkembang, namun disisi lain tidak sedikit pula perusahaan-perusahaan yang jatuh karena tidak mampu bersaing dengan perusahaan lain. Di samping mampu bertahan dan mengembangkan dirinya, pada dasarnya setiap perusahaan senantiasa berusaha untuk mendapatkan keuntungan yang optimal dengan jumlah pengorbanan yang dikeluarkan perusahaan, ini berarti perusahaan akan selalu berusaha untuk bekerja secara efektif dan efisien dalam memanfaatkan sumber daya yang dimiliki baik sumber daya alam, modal maupun sumber daya manusia.

Seperti yang diketahui pada dasarnya bahwa setiap perusahaan memiliki sumber daya manusia dan menjadi aset penting untuk 
mencapai tujuan bagi suatu perusahaan. Tanpa adanya sumber daya manusia yang baik maka perusahaan itu tidak akan berjalan dan sumber daya manusia merupakan satusatunya sumber daya yang tidak bisa ditiru seperti memiliki akal, persaan, keinginan, kemampuan, ketrampilan, pengetahuan dan karya. Semua potensi sumber daya manusia tersebut berpengaruh terhadap upaya perusahaan dalam pencapaian tujuan. Sumber daya manusia yang dimaksud adalah orang-orang yang memberikan tenaga, pikiran, bakat, kreativitas dan usahanya pada perusahaan, dengan harapan bahwa suatu saat yang akan datang perusahaan akan mengalami perkembangan yang pesat di dalam lingkup usaha dari perusahaannya dan menginginkan terciptanya kinerja yang baik dalam bidang pekerjaannya.

Gaya kepemimpinan dapat dikatakan sebagai cara dari seorang pemimpin dalam mengarahkan, mendorong dan mengatur seluruh unsur-unsur di dalam perusahaannya untuk mencapai suatu tujuan perusahaan yang diinginkan.

Pada berbagai bidang khususnya kehidupan berorganisasi, faktor manusia merupakan masalah utama disetiap kegiatan yang ada didalamnya. Organisasi merupakan kesatuan sosial yang dikoordinasikan secara sadar dengan sebuah batasan yang reaktif dapat diidentifikasikan, bekerja secara terus menerus untuk mencapai tujuan. Semua tindakan yang diambil dalam setiap kegiatan diprakarsai dan ditentukan oleh manusia yang menjadi anggota perusahaan. Perusahaan membutuhkan adanya faktor sumber daya manusia yang potensial baik pemimpin maupun karyawan pada pola tugas dan pengawasan yang merupakan penentu tercapainya tujuan perusahaan.

Sumber daya manusia merupakan tokoh sentral dalam organisasi maupun perusahaan. Agar aktivitas manajemen berjalan dengan baik, perusahaan harus memiliki karyawan yang berpengetahuan dan berketrampilan tinggi serta usaha untuk mengelola perusahaan seoptimal mungkin sehingga kinerja karyawan meningkat. Kinerja karyawan merupakan hasil atau prestasi kerja karyawan yang dinilai dari segi kualitas maupun kuantitas berdasarkan standar kerja yang ditentukan oleh pihak organisasi. Kinerja yang baik adalah kinerja yang optimal, yaitu kinerja yang sesuai standar organisasi dan mendukung tercapainya tujuan organisasi. Organisasi yang baik adalah organisasi yang berusaha meningkatkan kemampuan sumber daya manusianya, karena hal tersebut merupakan faktor kunci untuk meningkatkan kinerja karyawan.

Peningkatan kinerja karyawan akan membawa kemajuan bagi perusahaan untuk dapat bertahan dalam suatu persaingan lingkungan bisnis yang tidak stabil. Oleh karena itu upaya-upaya untuk meningkatkan kinerja karyawan merupakan tantangan manajemen yang paling serius karena keberhasilan untuk mencapai tujuan dan kelangsungan hidup perusahaan tergantung pada kualitas kinerja sumber daya manusia yang ada didalamnya. 
Motivasi dan disiplin kerja merupakan semangat untuk berperan serta secara aktif dalam proses, produksi. motivasi adalah menciptakan sikap dan perilaku seseorang agar melaksanakan tugasnya secara tepat waktu. Disiplin kerja merupakan prosedur yang mengkoreksi atau menghukum bawahan karena melanggar peraturan atau prosedur. Disiplin merupakan bentuk pengendalian diri pegawai dan pelaksanaan yang teratur dan menunjukan tingkat kesungguhan tim kerja di dalam perusahaan. Disiplin menuntut suatu hukuman terhadap karyawan yang gagal memenuhi standar-standar yang telah ditentukan organisasi. Tindakan disiplin yang dilaksanakan secara tidak benar adalah destruktif bagi karyawan dan organisasi, oleh karena itu tindakan disiplin haruslah tidak diterapkan secara sembarangan, melainkan memerlukan pertimbangan yang bijak.

Tindakan disiplin digunakan oleh organisasi untuk memberikan sanksi terhadap pelanggaran dari aturan-aturan kerja atau dari harapan-harapan. Sedangkan keluhankeluhan digunakan oleh karyawan yang merasa hak-haknya yang telah dilanggar oleh organisasi. Dalam hal ini, tindakan disiplin merupakan suatu pengurangan atau penurunan atau pemotongan gaji yang dipaksakan oleh atasan dalam hal imbalan karena suatu sebab, sedangkan keluhan adalah keluhan-keluhan yang dilakukan karyawan sehubungan dengan perlakuan yang tidak adil dalam distribusi imbalanimbalan atau hukuman-hukuman yang dilakukan organisasi.
Motivasi merupakan keinginan, hasrat motor penggerak dalam diri manusia, motivasi berhubungan dengan faktor psikologi manusia yang mencerminkan antara sikap, kebutuhan, dan kepuasan yang terjadi pada diri manusia sedangkan daya dorong yang diluar diri seseorang ditimbulkan oleh pimpinan. Motivasi mempersoalkan bagaimana cara mengarahkan daya dan potensi bawahan, agar mau bekerjasama secara produktif sehingga dapat mencapai dan mewujudkan tujuan perusahaan yang telah ditentukan. Pentingnya motivasi karena motivasi adalah hal yang menyebabkan, menyalurkan, dan mendukung prilaku manusia supaya mau bekerja sama secara giat sehingga mencapai hasil yang optimal. Suatu perusahaan dapat berkembang dengan baik dan mampu mencapai tujuannya, karena didasari oleh motivasi.

\section{METODE PENELITIAN}

Penelitian ini dilaksanakan di Palopo yakni pada PT. Financia Multi Finance Palopo Jalan Kelapa No. 58 Kota Palopo, jenis dan sumber data yang digunakan dua jenis data yaitu data primer dan data sekunder. Dalam hubungannya dengan hipotesis yang telah dikemukakan, maka akan diperlukan datadata yang relevan dan dapat menunjang kebenaran hipotesis tersebut adalah data primer dan data sekunder. Populasi dalam penelitian ini adalah seluruh karyawan pada PT. Financia Multi Finance Palopo yang jumlahnya sebanyak 80 orang sekaligus dijadikan sebagai sampel. Metode 
pengumpulan data terdiri dari penelitian pustaka dan penelitian lapangan.

\section{Metode Analisis}

Metode analisis yang digunakan dalam pembahasan proposal ini adalah Analisis Regresi Linier Berganda J.Suprianto, (2001:93) dengan formulasi sebagai berikut :

$Y=a+b_{1} X_{1}+b_{2} X_{2} b_{3} X_{3}+. . e$

Dimana :

$$
\begin{aligned}
& \mathrm{Y}=\text { Kinerja Karyawan } \\
& \mathrm{a}=\text { Konstanta } \\
& \mathrm{b}=\text { Koefisien regresi } \\
& \mathrm{X}_{1}=\text { Gaya Kepemimpinan } \\
& \mathrm{X}_{2}=\text { Motivasi } \\
& \mathrm{X}_{3}=\text { Disiplin Kerja }
\end{aligned}
$$

\section{HASIL PENELITIAN DAN PEMBAHASAN}

\section{Analisis Pembahasan}

\section{Analisis Regresi Berganda}

Analisis ini digunakan untuk mengetahui atau meramalkan besarnya pengaruh gaya kepemimpinan, motivasi dan disiplin kerja terhadap kinerja karyawan PT.Financia Multi Finance Palopo. Hasil pengolahan data dengan bantuan komputer program SPSS versi 20,0 didapatkan persamaan regresi :

$$
Y=0,614+0,875 X_{1}+0,072 X_{2}+0,001 X_{3}
$$

Hasil dari analisis tersebut dapat diinterpretasikan sebagai berikut:

1. Variabel gaya kepemimpinan, motivasi dan disiplin kerja mempunyai arah koefisien yang bertanda positif terhadap kinerja karyawan.
2. Koefisien gaya kepemimpinan memberikan nilai sebesar 0,875 yang berarti bahwa jika gaya kepemimpinan semakin baik dengan asumsi variabel lain tetap maka kinerja karyawan akan mengalami peningkatan sebesar 0,875 .

3. Koefisien motivasi memberikan nilai sebesar 0,072 yang berarti bahwa jika motivasi kerja semakin tinggi dengan asumsi variabel lain tetap maka kinerja karyawan akan mengalami peningkatan sebesar 0,072 .

4. Koefisien disiplin kerja memberikan nilai sebesar 0,001 yang berarti bahwa jika disiplijn kerja semakin kuat dengan asumsi variabel lain tetap maka kinerja karyawan akan mengalami peningkatan 0,001.

\section{Pengujian Hipotesis}

Untuk menguji tingkat hubungan dari variabel-variabel independen $\left(X_{1}, X_{2}\right.$ dan $\left.X_{3}\right)$ terhadap varabel dependen $(Y)$ digunakan uji t dan uji F. Uji t digunakan untuk menguji koefisien regresi secara individual, uji $F$ digunakan untuk menguji koefisien regresi secara serempak.

\section{a. Uji F ( Pengujian hipotesis secara simultan)}

Untuk menguji pengaruh variabel bebas secara bersama-sama diuji dengan menggunakan uji F. Hasil perhitungan regresi secara simultan diperoleh sebaga berikut: 
Tabel 2

Tanggapan responden mengenai gaya kepemimpinan

ANOVA $^{\mathrm{a}}$

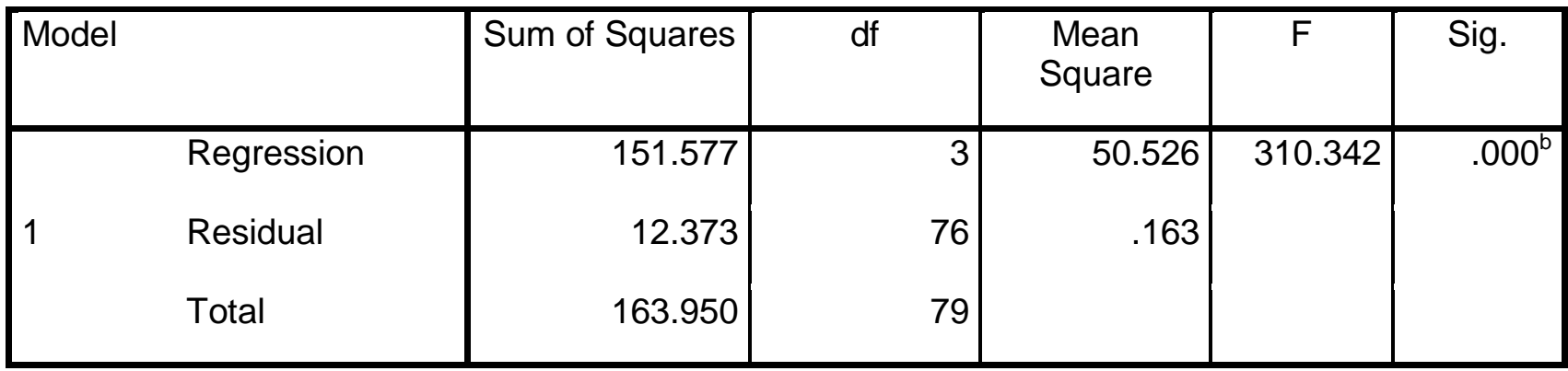

a. Dependent Variable: Kinerja Karyawan

b. Predictors: (Constant), Disiplin Kerja, Motivasi, Gaya Kepemimpinan Sumber Data Primer diolah 2014

\begin{abstract}
Pengujian pengaruh variabel bebas secara bersama-sama terhadap variabel terikatnya dilakukan dengan menggunakan uji F. Hasil perhitungan statistik menunjukkan nilai $\mathrm{F}$ hitung $=$ 310,342 dengan signifikansi $0,000^{\mathrm{b}}$.
\end{abstract} Dengan menggunakan batas signifikansi 0,05, maka diperoleh nilai signifikansi tersebut lebih kecil dari 0,05. Hal ini berarti bahwa hipotesis yang menyatakan bahwa secara simultan variabel gaya kepemimpinan, motivasi dan disiplin kerja mempunyai pengaruh terhadap kinerja karyawan.

\section{b. Koefisien Determinasi $\left(\mathbf{R}^{2}\right)$}

Koefisien determinasi merupakan besaran yang menunjukkan besarnya variasi variabel dependen yang dapat dijelaskan oleh variable independennya. Dengan kata lain, koefisien determinasi ini digunakan untuk mengukur seberapa jauh variabelvariabel bebas dalam menerangkan variabel terikatnya. Nilai koefisien determinasi ditentukan dengan nilai adjusted $R$ square sebagaimana dapat dilihat pada tabel2.

Tabel 3

Koefisien determinasi

\begin{tabular}{|l|r|r|r|r|}
\hline Model & R & R Square & Adjusted R Square & Std. Error of the Estimate \\
\hline 1 & $.962^{\mathrm{a}}$ & .925 & .922 & .40349 \\
\hline
\end{tabular}


Hasil perhitungan regresi linier berganda diketahui bahwa hubungan antara variabel gaya kepemimpinan, motivasi dan disiplin kerja terhadap kinerja karyawan PT. Financia Multi Finance Palopo adalah sangat kuat yaitu $\mathrm{R}=$ 0,962 .

Hasil perhitungan regresi dapat diketahui bahwa koefisien determinasi (adjusted $R^{2}$ ) yang diperoleh sebesar 0,992. Hal ini berarti $99,2 \%$ variasi variabel kinerja karyawan dapat dijelaskan oleh variabel gaya kepemimpinan, motivasi dan disiplin kerja, sedangkan sisanya sebesar $8 \%$ diterangkan oleh variabel lain yang tidak diajukan dalam penelitian ini.

\section{c. Uji t ( Uji Hipotesis Secara Parsial )}

Hipotesis 1, 2 dan 3 dalam penelitian ini diuji kebenarannya dengan menggunakan uji parsial. Pengujian dilakukan dengan melihat taraf signifikansi (pvalue), jika taraf signifikansi yang dihasilkan dari perhitungan di bawah 0,05 maka hipotesis diterima, sebaliknya jika taraf signifikansi hasil hitung lebih besar dari 0,05 maka hipotesis ditolak.

\section{Tabel 4: Hasil Uji t Secara Parsial}

\begin{tabular}{|l|c|c|}
\hline Variabel Bebas & t hitung & Sig. t \\
\hline $\begin{array}{l}\text { Gaya } \\
\text { Kepemimpinan (X1) }\end{array}$ & 25.796 & 0.000 \\
\hline Motivasi (X2) & 3.086 & 0.003 \\
\hline Disiplin Kerja (X3) & 0.051 & 0.960 \\
\hline
\end{tabular}

\section{Uji Hipotesis 1 ( H1 )}

Perumusan hipotesis:

$\mathrm{Ho}: \quad \beta i=0$ tidak ada pengaruh positif antara gaya kepemimpinan dengan kinerja karyawan.

$\mathrm{Ha}$ : $\quad \beta \mathrm{i}>0$ terdapat pengaruh positif antara gaya kepemimpinan dengan kinerja karyawan.

Dari tabel 3 terlihat bahwa hasil pengujian hipotesis gaya kepemimpinan menunjukkan nilai t hitung sebesar 25.796 dengan taraf signifikansi 0,000 . Taraf signifikansi tersebut lebih kecil dari 0,05, yang berarti bahwa hipotesis dalam penelitian ini menolak Ho dan menerima Ha. Dengan demikian dapat berarti bahwa hipotesis $\mathrm{H} 1$ “ Gaya Kepemimpinan mempunyai pengaruh positif terhadap Kinerja karyawan " diterima.

\section{Uji Hipotesis 2 ( H2 )}

Perumusan hipotesis:

Ho: $\quad \beta i=0$ tidak ada pengaruh positif antara motivasi kerja dengan kinerja karyawan.

$\mathrm{Ha}$ : $\quad \beta \mathrm{i}>0$ terdapat pengaruh positif antara motivasi kerja dengan kinerja karyawan.

Dari tabel 4 terlihat bahwa hasil pengujian hipotesis motivasi menunjukkan nilai $t$ hitung sebesar 3.086 dengan taraf signifikansi 0,003 . Taraf signifikansi hasil sebesar 0,003 tersebut lebih kecil dari 0,05, yang berarti bahwa hipotesis dalam penelitian ini menerima $\mathrm{Ha}$ dan menolak Ho. Dengan demikian dapat berarti bahwa hipotesis $\mathrm{H} 2$ “ 
Motivasi berpengaruh positif terhadap Kinerja karyawan " diterima.

\section{Uji Hipotesis 3 ( H3 )}

Perumusan hipotesis:

Ho: $\quad \beta i=0$ tidak ada pengaruh positif antara disiplin kerja dengan kinerja karyawan.

$\mathrm{Ha}$ : $\quad \beta \mathrm{i}>0$ terdapat pengaruh positif antara disiplin kerja dengan kinerja karyawan.

Dari tabel 4 terlihat bahwa hasil pengujian hipotesis disiplin kerja menunjukkan nilai $t$ hitung sebesar 0,051 dengan taraf signifikansi 0,960. Taraf signifikansi hitung sebesar 0,960 tersebut lebih besar dari 0,05, yang berarti bahwa hipotesis dalam penelitian ini menerima Ho dan menolak Ha. Dengan demikian berarti bahwa hipotesis H3 " Disiplin kerja mempunyai pengaruh yang signifikan terhadap Kinerja karyawan “ ditolak.

\section{Pembahasan}

Berdasarkan hasil pengujian secara statistik dapat terlihat dengan jelas bahwa secara parsial (individu) semua variabel bebas berpengaruh terhadap variabel terikat. Pengaruh yang diberikan ketiga variabel bebas tersebut bersifat positif artinya semakin tinggi gaya kepemimpinan, motivasi dan disiplin kerja maka mengakibatkan semakin tinggi pula kinerja karyawan yang dihasilkan. Hasil tersebut sesuai dengan hipotesis yang diajukan. Penjelasan dari masing-masing pengaruh variabel dijelaskan sebagai berikut:
1. Pengaruh Gaya Kepemimpinan terhadap Kinerja Karyawan

Hasil pengujian hipotesis $\left(\mathrm{H}_{1}\right)$ telah membuktikan terdapat pengaruh antara gaya kepemimpinan terhadap kinerja karyawan. Melalui hasil perhitungan yang telah dilakukan diperoleh nilai $\mathrm{t}$ hitung sebesar 25.796 dengan taraf signifikansi hasil sebesar 0,000 tersebut lebih kecil dari 0,05, dengan demikian $\mathrm{Ha}$ diterima dan Ho ditolak. Pengujian ini secara statistik membuktikan bahwa gaya kepemimpinan berpengaruh positif terhadap kinerja karyawan. Artinya bahwa ada pengaruh antara variabel gaya kepemimpinan terhadap kinerja karyawan di PT. Financia Multi Finance.

2. Pengaruh Motivasi terhadap Kinerja Karyawan

Hasil pengujian hipotesis $\left(\mathrm{H}_{2}\right)$ telah membuktikan terdapat pengaruh antara motivasi terhadap kinerja karyawan. Melalui hasil perhitungan yang telah dilakukan diperoleh nilai t hitung sebesar 3,086 dengan taraf signifikansi hasil sebesar 0,003 tersebut lebih kecil dari 0,05 , yang berarti bahwa hipotesis dalam penelitian ini menerima $\mathrm{Ha}$ dan menolak Ho. Pengujian ini secara statistik membuktikan bahwa motivasi berpengaruh positif terhadap kinerja karyawan. Artinya bahwa ada pengaruh antara variabel motivasi terhadap kinerja karyawan di PT Financia Multi Finance.

3. Pengaruh Disiplin Kerja terhadap Kinerja Karyawan 
Hasil pengujian hipotesis $\left(\mathrm{H}_{3}\right)$ telah membuktikan terdapat pengaruh antara disiplin kerja terhadap kinerja karyawan. Melalui hasil perhitungan yang telah dilakukan didapat nilai $\mathrm{t}$ hitung sebesar 0,028 dengan taraf signifikansi hitung sebesar 0,960 tersebut lebih besar dari 0,05 , yang berarti bahwa hipotesis dalam penelitian ini menerima Ho dan menolak Ha. Pengujian ini secara statistik membuktikan bahwa disiplin kerja berpengaruh positif terhadap kinerja karyawan tetapi pengaruh tidak signifikan. Artinya bahwa ada pengaruh antara variabel disiplin kerja terhadap kinerja karyawan di PT. Financia Multi Finance.

\section{SIMPULAN}

Dari data primer yang diperoleh dari penyebaran kuesioner maka dilakukan pengujian reliabilitas untuk mengetahui bahwa jawaban responden terhadap pernyataan konsisten dari waktu ke waktu.

Dari pembahasan yang telah diuraikan, maka dapat ditarik kesimpulan sebagai berikut:

1. Hasil pengujian hipotesis telah membuktikan terdapat pengaruh antara gaya kepemimpinan dengan kinerja karyawan. Pengujian membuktikan bahwa gaya Kepemimpinan memiliki pengaruh positif terhadap kinerja karyawan. Dilihat dari perhitungan yang telah dilakukan diperoleh nilai koefisien sebesar 0,316 dan nilai t hitung sebesar 3,784 dengan nilai signifikansi sebesar 0,000 tersebut lebih kecil dari 0,05 dengan demikian $\mathrm{Ha}$ diterima dan Ho ditolak. Hal ini mendukung penelitian yang dilakukan oleh penelitian menurut Rosari (2005) bahwa gaya kepemimpinan pada dasarnya menekankan untuk menghargai tujuan individu sehingga nantinya para individu akan memiliki keyakinan bahwa kinerja aktual akan melampaui harapan kinerja mereka.

2. Hasil pengujian hipotesis telah membuktikan terdapat pengaruh antara motivasi dengan kinerja karyawan. Pengujian membuktikan bahwa motivasi memiliki pengaruh positif terhadap kinerja karyawan. Dilihat dari perhitungan yang telah dilakukan diperoleh nili 50 sien sebesar 0,343 dan nilai t hitı ssar 3,628 dengan taraf signifikansi hasil sebesar 0,000 tersebut lebih kecil dari 0,05 , yang berarti bahwa hipotesis dalam penelitian ini menerima $\mathrm{Ha}$ dan menolak Ho.

3. Hasil pengujian hipotesis telah membuktikan terdapat pengaruh antara disiplin kerja dengan kinerja karyawan. Pengujian membuktikan bahwa disiplin kerja memiliki pengaruh positif terhadap kinerja karyawan. Dilihat dari perhitungan yang telah dilakukan diperoleh nilai koefisien sebesar 0,222 dan nilai t hitung 2,665 dengan taraf signifikansi hitung sebesar 0,009 tersebut lebih kecil dari 0,05 , yang berarti bahwa hipotesis dalam penelitian ini menolak Ho dan menerima 
Ha. Hal ini mendukung penelitian yang dilakukan oleh Budi Setiyawan dan Waridin (2006) yang mengungkapkan bahwa disiplin kerja karyawan bagian dari faktor kinerja.

4. Gaya kepemimpinan memiliki pengaruh yang paling kuat terhadap kinerja karyawan PT. Financia Multi Finance.

\section{SARAN}

Berdasarkan kesimpulan yang telah dilakukan maka saran yang dapat diberikan dalam penelitian ini yaitu:

\section{Bagi Perusahaan}

Hendaknya perusahaan dalam meningkatkan kinerja karyawan lebih menitikberatkan pada gaya kepemimpinan, dilihat dari kuesioner yang telah diisi oleh karyawan PT.Financia Multi Financia tersebut diperoleh data bahwa karyawan memiliki kinerja yang baik apabila didukung dengan gaya kepemimpinan yang tepat. Hal itu sebaiknya di pertahankan dan ditingkatkan dengan cara berperilaku sebagai pemimpin yang dalam kepemimpinannya dapat memotivasi dan mengikutsertakan karyawan dalam mengambil suatu keputusan yang berhubungan dengan karyawan itu sendiri sehingga terjadi sinkronisasi dan sejalan dengan aturan perusahaan.

2. Bagi Penelitian Selanjutnya

Hasil Uji $\mathrm{R}^{2}$ menunjukkan masih ada variabel-variabel lain yang harus diperhatikan dalam penelitian ini. Penelitian-penelitian lebih lanjut, hendaknya menambah variabel lain yang dapat mempengaruhi kinerja karyawan, karena dengan semakin baik kinerja dari karyawan maka akan berpengaruh baik juga bagi perusahaan.

\section{DAFTAR PUSTAKA}

Algifari. 2000. Analisis: Teori dan Kasus Solusi. BPFE. Yogyakarta.

Guritno, Bambang dan Waridin. 2005. Pengaruh Persepsi Karyawan Mengenai Perilaku Kepemimpinan, Kepuasan Kerja Dan Motivasi Terhadap Kinerja. JRBI. Vol 1. No 1. Hal: 63-74.

Hakim, Abdul. 2006. Analisis Pengaruh Motivasi, Komitmen Organisasi Dan Iklim Organisasi Terhadap Kinerja Pegawai Pada Dinas Perhubungan Dan Telekomunikasi Provinsi Jawa Tengah. JRBI. Vol 2. No 2. Hal: 165180.

Handoko, T. Hani. 2003. Manajemen Edisi 2. BPFE. Yogyakarta.

Hasibuan, Malayu. 2004. Manajemen Sumber Daya Manusia. PT Bumi Aksara. Jakarta.

Madura, Jeff. 2007. Pengantar Bisnis. Edisi Keempat. Salemba Empat: Jakarta.

Malthis, R.L dan Jackson. 2001. Manajemen Sumber Daya Manusia. Salemba Empat. Jakarta.

Masrukhin dan Waridin. 2004. Pengaruh Motivasi Kerja, Kepuasan Kerja, Budaya Organisasi Dan Kepemimpinan Terhadap Kinerja Pegawai. EKOBIS. Vol 7. No 2. Hal: 197-209. 
Rosari, Reni. 2005. Analisis Gaya Kepemimpinan Dosen-Dosen Di Fakultas Ekonomi UGM Yogyakarta. Jurnal Telaah Bisnis. Vol 6. No 1. Hal: 87-109.

Robbins, Stephen. P. 2006. Perilaku organisasi. Edisi Bahasa Indonesia. PT Indeks Kelompok GRAMEDIA. Jakarta.

Robbins, Stephen. P. dan Mary Coulter. 2005. Manajemen. PT INDEKS Kelompok Gramedia. Jakarta.

Rivai, Veithzal. 2004. Manajemen Sumber Daya Manusia Untuk Perusahaan. PT RAJAGRAFINDO PERSADA. Jakarta

Rivai, Veithzal dan Basri. 2005. Performance Appraisal: Sistem Yang Tepat Untuk Menilai Kinerja Karyawan Dan Meningkatkan Daya Saing Perusahaan. PT RAJAGRAFINDO PERSADA. Jakarta.

Setiyawan, Budi dan Waridin. 2006. Pengaruh Disiplin Kerja Karyawan Dan Budaya Organisasi Terhadap Kinerja Di Divisi Radiologi RSUP Dokter Kariadi Semarang. JRBI. Vol 2. No 2. Hal: 181-198.

Siagian, Sondong. P. 2002. Kiat Meningkatkan Produktivitas Kerja. PT Rineka Cipta. Jakarta.

Simamora, Henry. 1997. Manajemen Sumber Daya Manusia. STIE YKPN. Yogyakarta.

Suharto dan Cahyo. 2005. Pengaruh Budaya Organisasi, Kepemimpinan Dan Motivasi Terhadap Kinerja Sumber Daya Manusia Di Sekretariat DPRD Propinsi Jawa Tengah. JRBI. Vol 1. No 1. Hal: 13-30.

Supranto, J. 2001. Statistik: Teori dan Aplikasi. Edisi keenam. Erlangga. Jakarta.
Suranta, Sri. 2002. Dampak Motivasi Karyawan Pada Hubungan Antara Gaya Kepemimpinan Dengan Kinerja Karyawan Perusahaan Bisnis. Empirika.Vol 15. No 2. Hal: 116-138.

Tampubolon, Biatna. D. 2007. Analisis Faktor Gaya Kepemimpinan Dan Faktor Etos Kerja Terhadap Kinerja Pegawai Pada Organisasi Yang Telah Menerapkan SNI 19-9001-2001. Jurnal Standardisasi. No 9. Hal: 106-115.

Tika, P. 2006. Budaya Organisasi Dan Peningkatan Kinerja Perusahaan. PT Bumi Aksara. Jakarta.

Yuwalliatin, Sitty. 2006. Pengaruh Budaya Organisasi, Motivasi Dan Komitmen Terhadap Kinerja Serta Pengaruhnya Terhadap Keunggulan Kompetitif Dosen UNISULA Semarang. EKOBIS. Vol 7. No 2. Hal: 241-256. 